\title{
PENGARUH PROFITABILITAS FIRM SIZE TERHADAP DIVIDEND PAYOUT RATIO DIMODERASI LIKUIDITAS PADA BUMN INDONESIA
}

\author{
Nik Amah'), Efa Dwi Prasetyowati ${ }^{2)}$ \\ Fakultas Ekonomi dan Bisnis Universitas PGRI Madiun \\ email: sigmaku87@gmail.com ${ }^{1)}$, efadwi04@gmail.com²)
}

\begin{abstract}
The purpose of this study aims to empirically examine the effect of profitability and firm size on the dividend payout ratio with liquidity as a moderating variable. This population, namely the BUMN companies listed on the Indonesia Stock Exchange (IDX) for the period 2013-2017. The type of research used is descriptive quantitative. The sampling technique using purposive sampling method. Based on the existing criteria, there were 15 BUMN companies that became the research sample. Data analysis techniques used in this study are multiple linear regression analysis and Moderated Regression Analysis (MRA). The results of this study indicate that profitability does not affect the dividend payout ratio. Firm size affects the dividend payout ratio. Liquidity moderates the effect of profitability on the dividend payout ratio. Liquidity does not moderate the effect of firm size on the dividend payout ratio.
\end{abstract}

Keywords: Dividend Payout Ratio, Liquidity, Profitability and Firm Size

\begin{abstract}
Abstrak
Tujuan penelitian ini bertujuan untuk menguji secara empiris pengaruh profitabilitas dan firm size terhadap dividend payout ratio dengan likuiditas sebagai variabel moderating. Populasi ini, yaitu pada perusahaan BUMN yang terdaftar di Bursa Efek Indonesia (BEI) Periode 2013- 2017. Jenis penelitian yang digunakan yaitu deskriptif kuantitatif. Teknik pengambilan sampel dengan metode purposive sampling. Berdasarkan kriteria yang ada, didapatkan 15 perusahaan BUMN yang menjadi sampel penelitian. Teknik analisis data yang digunakan dalam penelian ini adalah analisis regresi linier berganda dan Moderated Regression Analysis (MRA). Hasil penelitian ini menunjukkan profotabilitas tidak berpengaruh terhadap dividend payout ratio. Firm size berpengaruh terhadap dividend payout ratio. Likuiditas memoderasi pengaruh profitabilitas terhadap dividend payout ratio. Likuiditas tidak memoderasi pengaruh firm size terhadap dividend payout ratio.
\end{abstract}

Kata Kunci : Dividend Payout Ratio, Likuidias,Profitabilitas dan Firm Size

\section{PENDAHULUAN}

Adanya kemajuan teknologi dan ilmu pengetahuan yang semakin pesat berdampak pada perekonomian negara yang juga ikut mengalami perkembangan. Salah satu contoh yang merasakan dampak adanya IPTEK adalah pasar modal. Pasar modal di Indonesia memegang peranan penting dalam menghimpun dana dari investor yang akan menanamkan modalnya. Pada basisnya investor dalam menginvestasikan dana memiliki tujuan yaitu untuk memperoleh imbalan (return) atas investasinya, baik berupa pendapatan dividen. Perusahaan akan mendistribusikan sebagian profitnya sesuai proporsi dan merata kepada para pemegang saham sebagai bentuk imbal balik atas dana yang ditanamkan. Pembagian keuntungan disebut juga dengan dividen.

Membayarkan besaran dividen kepada pemegang saham harus disesuaikan dengan total lembar saham yang ditanamkan dan pembayaran dilakukan untuk tiap lembarnya. Berdasarkan keputusan Rapat Umum Pemegang Saham atau bisa disingkat dengan RUPS, perusahaan akan membagikan dividen kepada pemegang saham apabila memperoleh profit dalam satu periode tertentu. Setiap perusahaan tidak selalu sama dalam menerapkan prosedur pembagian dividen. Perusahaan perlu menggunakan kebijakan terkait besar kecil laba yang akan diberikan kepada pemegang saham, bisa disebut dengan Dividend Payout Ratio (DPR) dan jumlah laba yang 
akan ditahan oleh perusahaan (Sabri, Deviyanti dan Kurniawan, 2017).

Kebijakan dividen menjadi suatu pertimbangan yang akan sangat berat karena akan melibatkan dua kelompok yang berkepentingan dan bertentangan. Pihak yang berkepentingan yaitu pemegang saham yang mengharapkan pembagian dividen, disisi lain perusahaan terhadap laba ditahan. Pihak manajemen umumnya menahan kas mempunyai alasan tersendiri yaitu untuk berinvestasi agar dapat meningkatkan pertumbuhan perusahaan di tahun berikutnya. Dividend payout ratio merupakan suatu rasio bunga kepada pemegang saham. Rasio ini menunjukkan kemampuan perusahaan dalam persentase laba bersih yang dibayarkan dalam satu tahun dalam bentuk dividen tunai (Samryn, 2015:255).

Beberapa penelitian ini pernah dilakukan diantaranya oleh Atmoko dkk (2017) yang mengklain bahwa return on assets, debt to equity ratio dan firm size berpengaruh positif dan signifikan terhadap dividend payout ratio pada perusahaan perbankan yang terdaftar di BEI periode 2011- 2015. Sedangkan hasil penelitian dari Sabri dkk (2017) menunjukkan bahwa cash ratio berpengaruh negatif dan tidak signifikan terhadap dividend payout ratio, debt to equity ratio dan total assets turnover berpengaruh negatif dan signifikan terhadap dividend payout ratio, net profit margin memiliki pengaruh positif dan tidak signifikan terhadap dividend payout ratio pada perusahaan BUMN yang terdaftar di BEI tahun 2011-2014.

\section{Tujuan Penelitian}

1. Untuk menguji secara empiris pengaruh rasio profitabilitas (return on assets) terhadap dividend payout ratio pada perusahaan BUMN di Bursa Efek Indonesia periode 2013-2017
2. Untuk menguji secara empiris pengaruh firm size terhadap dividend payout ratio pada perusahaan BUMN di Bursa Efek Indonesia periode 2013-2017

3. Untuk menguji secara empiris rasio likuiditas (current ratio) memoderasi pengaruh rasio profitabilitas (return on assets) terhadap dividend payout ratio pada perusahaan BUMN di Bursa Efek Indonesia periode 2013-2017

4. Untuk menguji secara empiris rasio likuiditas (current ratio) memoderasi pengaruh firm size terhadap dividend payout ratio pada perusahaan BUMN di Bursa Efek Indonesia periode 20132017

\section{KAJIAN TEORI DAN PENGEMBANGAN HIPOTESIS \\ Dividend Payout Ratio}

Kebijakan dividen merupakan sebuah keputusan yang akan di ambil manaejem apakah laba yang diperoleh akan dibagikan kepada pemegang saham sebagai dividen atau laba ditahan yang akan digunakan untuk investasi dimasa mendatang. Kebijakan dividen berhubungan dengan besar kecilnya dividend payout ratio. Dividen adalah pembagian laba kepada pemegang saham yang sesuai dengan jumlah laba yang dimiliki. Dividend Payout Ratio adalah rasio yang menunjukkan besaran persentase laba bersih setelah pajak yang dibagikan dalam satu tahun dalam bentuk dividen kepada pemegang saham. Semakin besar laba ditahan semakin sedikit dividen yang dibagikan, dan sebaliknya semakin kecil laba ditahan semakin besar dividen yang dibagikan. (Ano, Murni, dan Rate, 2014).

\section{Profitabilitas}

Rasio profitabilitas adalah rasio yang digunakan untuk mengukur kemampuan perusahaan dalam memperloleh laba yang dihasilkan dari 
penjualan dan pendapatan investasi. Semakin baik rasio profitabilitas maka semakin tinggi kemampuan perusahaan dalam memperoleh keuntungan dan sebaliknya jika semakin buruk rasio profitabilitas maka semakin rendah kemampuan perusahaan dalam memperoleh keuntungan (Fahmi, 2014:81). Untuk mengukur profitabilitas peneliti menggunakan Return on Assets (ROA). Jika perusahaan memiliki profitabilitas yang buruk maka perusahaan tersebut tidak dapat membagikan dividen atau meningkatkan dividen.

\section{Firm Size}

Firm Size atau ukuran perusahaan adalah rata-rata penjualan bersih perusahaan untuk tahun yang berkaitan sampai dengan beberapa tahun (Atmoko dkk, 2017). Firm size juga menunjukkan perusahaan yang besar dengan penjualan yang lebih baik seharusnya membayar dividen yang tinggi. Dengan demikian para pemegang saham akan menaruh kepercayaan yang besar kepada perusahaan tersebut. Sedangkan ukuran perusahaan yang kecil akan kesulitan dalam mengaksesnya di pasar modal.

\section{Likuiditas}

Rasio likuiditas adalah rasio yang mengukur kesanggupan perusahaan dalam mencukupi atau melunasi kewajiban jangka pendeknya dengan waktu yang tepat. Sedangkan Fred Weston mengatakan bahwa rasio likuiditas merupakan rasio yang mampu menunjukan perusahaan dalam mencukupi kewajiban jangka pendek (Kasmir, 2010:110). Pada penelitian ini untuk mengukur rasio likuiditas yaitu dengan menggunakan current ratio. Jika kewajiban jangka pendek meningkat, maka dividen akan menurun karena perusahaan lebih memilih untuk melunasi kewajiban jangka pendek yang dihasilkan dari pada memberikan dividen kepada pemegang saham.

\section{Kerangka Berpikir}

Penelitian ini bertujuan untuk melihat seberapa besar pengaruh profitabilitas dan firm size terhadap dividend payout ratio dengan likuiditas sebagai variabel moderating. Kerangka berpikir yang mendasari penelitian ini adalah sebagai berikut:

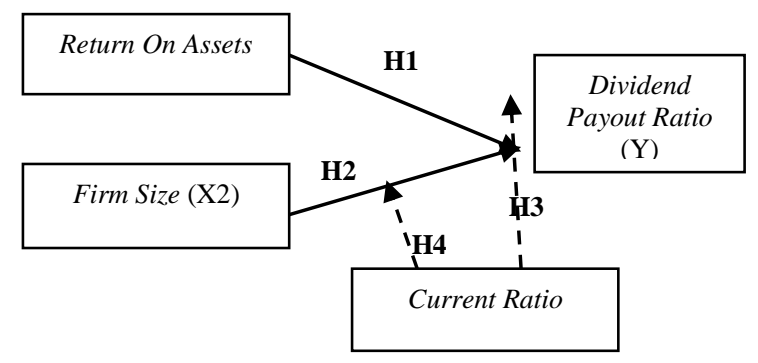

Gambar 2.1 Kerangka Berpikir

Keterangan:

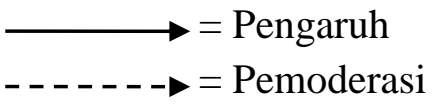

\section{Hipotesis}

Pengaruh Profitabilitas (Return on Assets) terhadap Dividend Payout Ratio

Rasio profitabilitas adalah kesanggupan perusahaan dalam meraup laba (keuntungan) menurut Kasmir (2010:115). Pengertian yang sama juga disampaikan oleh Fahmi (2014:81). Profitabilitas adalah rasio yang diberdayakan untuk mengukur kesanggupan perusahaan dalam mendapatkan laba yang dihasilkan dari penjualan dan pendapatan investasi. Semakin baik rasio profitabilitas maka semakin tinggi kemampuan perusahaan dalam memperoleh keuntungan dan sebaliknya jika semakin buruk rasio profitabilitas maka semakin rendah kemampuan perusahaan dalam memperoleh keuntungan.

Hasil penelitian yang sama juga pernah dilakukan oleh Yuwono dkk (2018) ROA (Return on Assets) berpengaruh terhadap dividend payout ratio. Sedangakan penelitian yang pernah dilakukan oleh 
Karauan (2017) bahwa ROA (Return on Assets) tidak berpengaruh signifikan terhadap dividend payout ratio.

H1 : Profitabilitas berpengaruh terhadap Dividend Payout Ratio pada perusahaan BUMN di Bursa Efek Indonesia periode 2013- 2017

\section{Pengaruh Firm Size terhadap Dividend Payout Ratio}

Ukuran perusahaan (Firm Size) adalah rata-rata dari penjualan bersih untuk periode yang berkaitan sampai dengan beberapa periode berikutnya. Memperoleh laba bersih sesudah pajak merupakan keinginan suatu perusahaan, karena dengan memperoleh laba tersebut mampu meningkatkan sendiri. Jika total aset semakin tinggi dapat dijadikan sebuah indikator mendistribusikan dividen kepada pemegang saham atau lebih memilih untuk ditahan kembali karena jika total aset semakin meningkat juga mempengaruhi perusahaan dalam memperoleh modal.

Menurut Yuwono dkk (2018) bahwa firm size berpengaruh terhadap dividend payout ratio. Firm size berpengaruh positif dan signifikan terhadap dividend payout ratio penelitian yang pernah dilakukan oleh Atmoko dkk (2017). Berbeda dari penelitian yang sebelumnya hasil penelitian Harun (2018) menunjukkan bahwa firm size tidak berpengaruh terhadap dividend payout ratio.

H2 : Firm Size berpengaruh terhadap Dividend Payout Ratio pada perusahaan BUMN di Bursa Efek Indonesia periode 2013- 2017

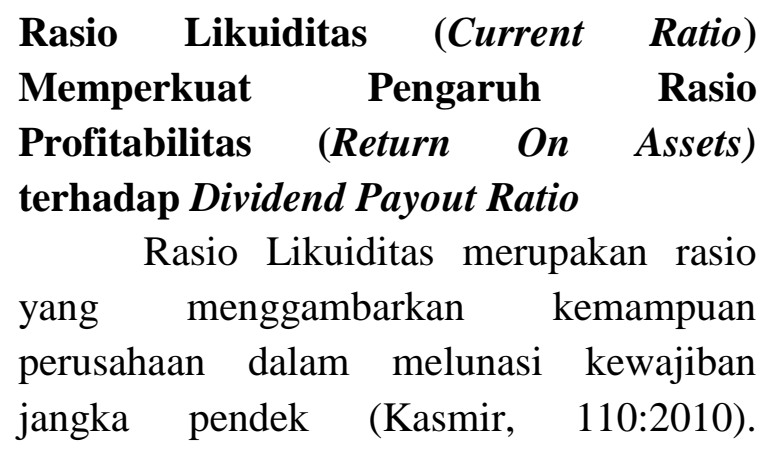

Pengertian yang sama juga pernah dismpaikan oleh Fahmi (2014:69) Likuiditas adalah Rasio yang digunakan untuk mengukur kemampuan suatu perusahaan dalam memenuhi liabilitas lancar secara tepat waktu.

Penelitian yang pernah dilakukan oleh Yunisari dkk (2018) mengatakan bahwa Likuiditas tidak memoderasi perngaruh profitabilitas terhadap kebijakan dividen. Berbeda dari penelitian yang pernah dilakukan sebelumnya, hasil penelitian dari Parmitasari dkk (2015) bahwa likuiditas (current ratio) sebagai variabel moderating mampu memperkuat pengaruh profitabilitas (return on assets) terhadap kebijakan dividen.

H3 : Likuiditas (Current Ratio) memoderasi pengaruh rasio profitabilitas (Return On Assets) terhadap Dividend Payout Ratio pada perusahaan BUMN di Bursa Efek Indonesia periode 2013- 2017

Rasio Likuiditas (Current Ratio) Memperkuat Pengaruh Firm Size terhadap Dividend Payout Ratio

Ukuran perusahaan dapat dikategorikan besar atau kecil suatu perusahaan dengan beberapa metode, antara lain total aset, jumlah karyawan dll. Ukuran perusahaan dasarnya dibagi menjadi 3 yaitu perusahaan besar, perusahaan menengah dan perusahaan kecil. Semakin besar aset suatu perusahaan maka perusahaan tersebut memiliki kestabilan dalam kondisi keuangan, sehingga perusahaan tersebut akan lebih mudah dalam memperoleh modal daripada perusahaan yang memiliki aset rendah.

Menurut Arjana dkk (2017) mengatakan bahwa firm size berpengaruh terhadap dividen payout ratio. Hasil penelitian yang sama juga pernah dilakukan oleh Sanjaya dkk (2018) bahwa firm size berpengaruh positif dan signifikan terhadap dividend payout ratio. 
H4 : Likuiditas (Current Ratio) memoderasi pengaruh Firm Size terhadap Dividend Payout Ratio pada perusahaan BUMN di Bursa Efek Indonesia periode 2013- 2017.

\section{METODE PENELITIAN}

Menurut Gujarati dalam Ghozali (2016:93) analisis regresi linier adalah mengenai ketergantungan variabel dependen dengan satu atau lebih variabel independen dengan tujuan untuk memprediksi rata-rata populasi atau variabel dependen berdasarkan nilai variabel independen yang diketahui. Penelitian ini merupakan penelitian yang menggambarkan korelasi sebab akibat antara variabel dependen dan variabel independen.

Populasi mendefinisikan kualitas dan karakteristik dari wilayah generalisasi terdiri dari obyek/subyek yang telah diterapkan oleh peneliti yang untuk dipelajari kemudian ditarik kesimpulan (Sugiyono, 2016:80). Populasi dalam penelitian ini adalah perusahaan BUMN (Badan Usaha Milik Negara) yang terdaftar di Bursa Efek Indonesia periode 20132017. Total populasi adalah 20 perusahaan BUMN (Bursa Efek Indonesia 2013-2017). Sampel merupakan bagian jumlah dan karakteristik yang dimiliki oleh populasi tersebut (Sugiyono, 2016:80-81). Sampel yang diambil dengan menggunakan metode purposive sampling.

Jenis data dalam penelitian ini adalah data sekunder yang di ambil dari laporan keungan perusahaan BUMN yang membagikan dividen setiap tahun secara terus-menerus di Bursa Efek Indonesia (BEI). Sumber data yang diperoleh dari situs resmi Bursa Efek Indonesia (BEI) selama periode penelitian tahun 2013-2017. Data yang dikumpulkan dapat diakses melalui www.idx.co.id. Teknik pengumpulan data yang dilakukan dengan metode dokumentasi. Metode dokumentasi adalah metode yang digunakan untuk menelusuri data historis.

Teknik analisis data dalam penelitian kuantitatif menggunakan teknik statistik dengan bantuan program IBM SPSS Statistics versi 22. Metode dalam analisi ini menggunakan statistik deskriptif, regresi linier berganda dan moderated redression analiysis MRA.

\section{HASIL DAN PEMBAHASAN}

Tabel 1. Hasil Pengujian Uji Descriptive Statistics

\begin{tabular}{lrrrrr}
\hline & N & Min & Max & Mean & Std. Deviation \\
\hline DPR & 45 & 0,06 & 0,42 & 0,2178 & 0,08088 \\
ROA & 45 & 0,01 & 0,09 & 0,0338 & 0,01848 \\
SIZE & 45 & 18,69 & 32,22 & 24,3416 & 4,83345 \\
CR & 45 & 1,00 & 2,43 & 1,3391 & 0,30804 \\
Valid N & & & & & \\
(listwise) & 45 & & & &
\end{tabular}

Sumber: Hasil olah data SPSS v.22

\section{Dividend Payout Ratio}

Pada tabel di atas menunjukkan bahwa variabel dividend payout ratio memiliki nilai minimum 0,06 , nilai maximum 0,42 , rata-rata dividend payout ratio sebesar 0,2178 dan nilai standar deviasi atau simpangan baku sebesar 0,08088. Nilai rata-rata (mean) dividend payout ratio lebih tinggi dibandingkan dengan nilai standar deviasi dividend payout ratio, maka dikatakan bahwa dividend payout ratio telah terdistribusi baik.

\section{Return on Assets}

Pada return on assets memiliki nilai minimum 0,01, nilai maximum 0,09. Sedangkan untuk nilai rata-rata (mean) return on assets sebesar 0,0338 dan nilai standar deviasi atau simpangan baku sebesar 0,01848. Nilai rata-rata (mean) return on assets lebih tinggi dibandingkan dengan nilai standar deviasi return on assets, maka dinyatakan return on assets telah terdistribusi baik.

\section{Firm Size}


Pada tabel diatas menunjukkan bahwa variabel firm size memiliki nilai minimum 18,69, nilai maximum 32,22, rata-rata (mean) firm size sebesar 24,3416 dan nilai standar deviasi atau simpangan baku sebesar 4,83345. Nilai rata-rata (mean) firm size lebih tinggi dibandingkan dengan nilai standar deviasi firm size, maka dikatakan bahwa firm size telah terdistribusi baik.

\section{Current Ratio}

Pada current ratio memiliki nilai minimum 1,00, nilai maximum 2,43. Sedangkan untuk current ratio nilai ratarata (mean) sebesar 1,3391 dan nilai standar deviasi atau simpangan baku sebesar 0,30804. Nilai rata-rata (mean) current ratio lebih tinggi dibandingkan dengan nilai standar deviasi current ratio, maka dapat dikatakan bahwa current ratio telah terdistribusi baik

Tabel 2. Hasil Uji Normalitas One-Sample Kolmogorov-Smirnov Test

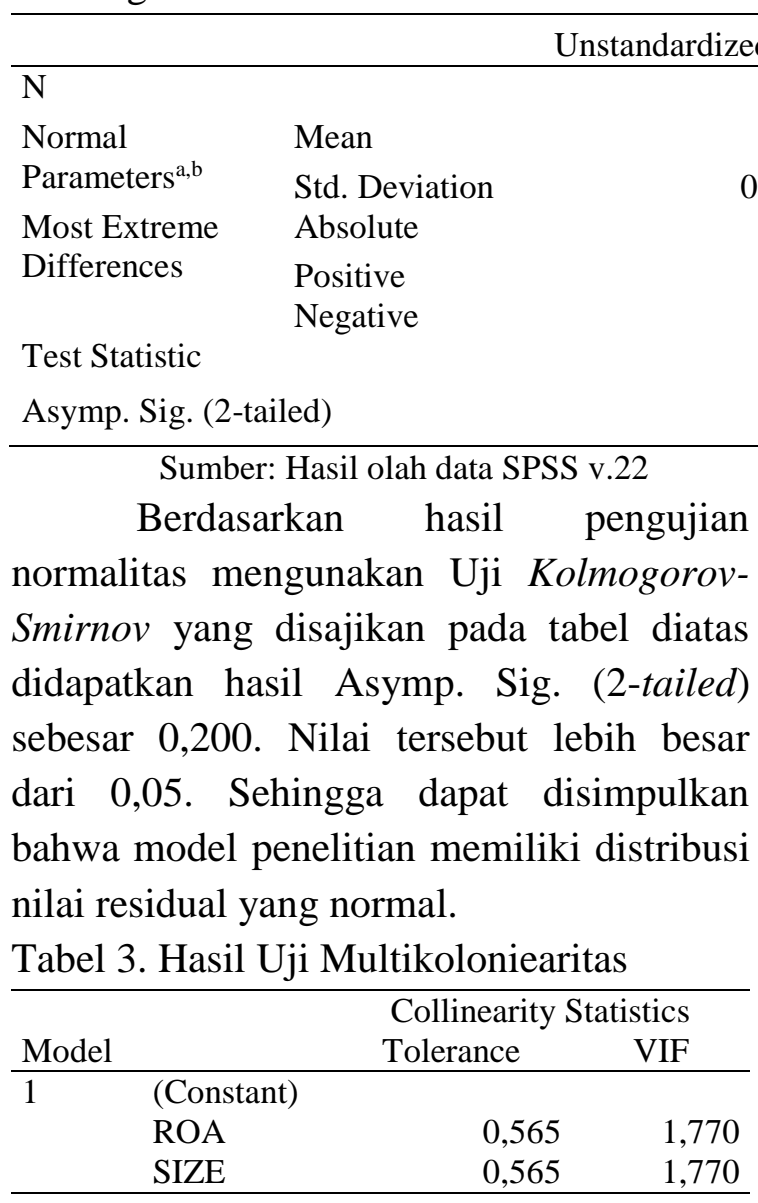

Sumber: Hasil olah data SPSS v. 22

Tabel diatas menunjukkan nilai VIF dari masing-masing variabel independen lebih kecil atau kurang dari 10. Nilai tolerance $\geq 0,10$ atau sama dengan nilai VIF $\leq 10$. Sehingga dapat diambil kesimpulan bahwa tidak terdapat korelasi antar variabel independen.

Tabel 4. Hasil Uji Autokolerasi

\begin{tabular}{lccccr}
\hline $\begin{array}{c}\text { Mod } \\
\text { el }\end{array}$ & $\mathrm{R}$ & $\begin{array}{c}\mathrm{R} \\
\text { Square }\end{array}$ & $\begin{array}{c}\text { Adjusted R } \\
\text { Square }\end{array}$ & $\begin{array}{c}\text { Std. Error } \\
\text { of the } \\
\text { Estimate }\end{array}$ & $\begin{array}{c}\text { Durbin- } \\
\text { Watson }\end{array}$ \\
\hline 1 & $0,574^{\mathrm{a}}$ & 0,330 & 0,294 & 0,06799 & 2,238 \\
\hline \multicolumn{5}{c}{ Sumber: Hasil olah data SPSS v.22 } \\
Tabel diatas menunjukkan hasil uji
\end{tabular}

Durbin Watson. Nilai durbin watson pada output pengujian yaitu sebesar 2,238. Berdasarkan tabel durbin watson, diketahui bahwa nilai dU untuk jumlah data 40 dan jumlah variabel independen 2 yaitu 1,600 sehingga nilai 4-dU sebesar 2,400 (41,600). Nilai DW berada diantara dU dan 4Du atau 1,600 $<2,238<2,400$. Sehingga dapat disimpulkan tidak terdapat aytokorelasi pada model penelitian.

0,0000 Gabel 5. Hasil Uji Heteroskedastisitas 0,06621

\begin{tabular}{|c|c|c|c|c|}
\hline \multirow{2}{*}{$\begin{array}{l}0, \\
0, \mathrm{Mod}\end{array}$} & & \multicolumn{2}{|c|}{ Unstandardized Coefficients } & Coefficieı \\
\hline & & B & Std. Error & Beta \\
\hline$-0,1$ & (Constant) & 0,451 & 0,060 & \\
\hline 0 & ROA & $-0,022$ & 0,784 & \\
\hline , & SIZE & $-0,010$ & 0,003 & \\
\hline
\end{tabular}

0,2 SQimber: Hasil olah data SPSS v.22

Berdasarkan hasil uji glejser memiliki nilai signifikansi dalam regresi dengan variabel Absolute Residual nilai signifikansi > 0,05, dapat disimpulkan bahwa uji glejser dalam penelitian ini terbebas dari heteroskedastisitas.

Tabel 6. Hasil Uji Regresi Linier Berganda

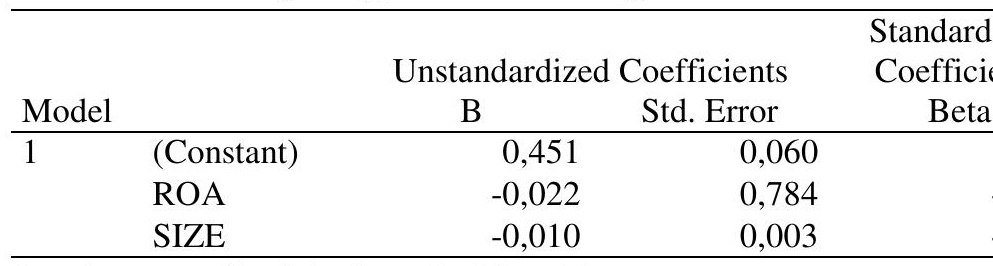

Sumber: Hasil olah data SPSS v.22

1. Return on Assets dengan nilai signifikansi 0,978 menunjukkan arah 
pengaruh negatif $(\beta=-0,022)$. Artinya semakin besar nilai return on assets, maka semakin kecil dividend payout ratio.

2. Firm size dengan nilai signifikansi 0,003 menunjukkan arah pengaruh posistif $(\beta=-0,010)$. Artinya semakin kecil nilai firm size, maka semakin besar dividend payout ratio. b) Berdasarkan hasil pengujian diketahui bahwa didapat thitung dari variabel Firm Size sebesar -3,189 dengan nilai sig. 0,003 . Nilai $t_{\text {hitung }}-3,189$ dan $t_{\text {tabel }} 2,028$ ( $\left.\mathrm{t}_{\text {hitung }}<\mathrm{t}_{\text {tabel }}\right)$. Nilai sig. tersebut kecil besar dari nilai alpha 0,05 atau 0,003 < 0,05. Hal ini menunjukkan bahwa Firm Size berpengaruh terhadap Dividend Payout Ratio.

Tabel 9. Hasil Moderated Regression Analysisis

Tabel 7. Hasil Uji Koefisien Determinan $\left(\mathrm{R}^{2}\right)$

\begin{tabular}{|c|c|c|c|c|}
\hline $\begin{array}{l}\text { Mod } \\
\text { el }\end{array}$ & $\mathrm{R}$ & $\begin{array}{c}\mathrm{R} \\
\text { Square }\end{array}$ & $\begin{array}{l}\text { Adjusted R } \\
\text { Square }\end{array}$ & $\begin{array}{l}\text { Std. Error } \\
\text { of the } \\
\text { Estimate }\end{array}$ \\
\hline 1 & $0,574^{\mathrm{a}}$ & 0,330 & 0,294 & 0,06799 \\
\hline
\end{tabular}

Sumber: Hasil olah data SPSS v.22

Tabel diatas menunjukkan nilai Adjusted $R$ Square sebesar 0,294 atau 29,4 $\%$. Nilai tersebut menunjukkan bahwa variabel profitabilitas, dan firm size mampu memprediksi variabel dividend payout ratio sebesar $29,4 \%$. Sedangkan sisanya sebesar $70,6 \%$ dijelaskan oleh faktor lain diluar model penelitian.

Tabel 8. Hasil Uji Parsial (Uji t)

\begin{tabular}{llrr} 
Model & & $\mathrm{T}$ & Sig. \\
\hline 1 & (Constant) & 7,530 & 0,000 \\
& ROA & $-0,027$ & 0,978 \\
& SIZE & $-3,189$ & 0,003 \\
\hline
\end{tabular}

Sumber: Hasil olah data SPSS v.22

a) Berdasarkan hasil pengujian diketahui bahwa thitung dari variabel ROA sebesar $-0,027$ dengan nilai sig. 0,978. Nilai $t_{\text {hitung }}-0.027$ dan $t_{\text {tabel }} 2,028$ (thitung < $\left.\mathrm{t}_{\text {tabel}}\right)$. Nilai sig. tersebut lebih besar dari nilai alpha 0,05 atau 0,978>0,05. Hal ini menunjukkan bahwa ROA tidak berpengaruh terhadap Dividend payout ratio.

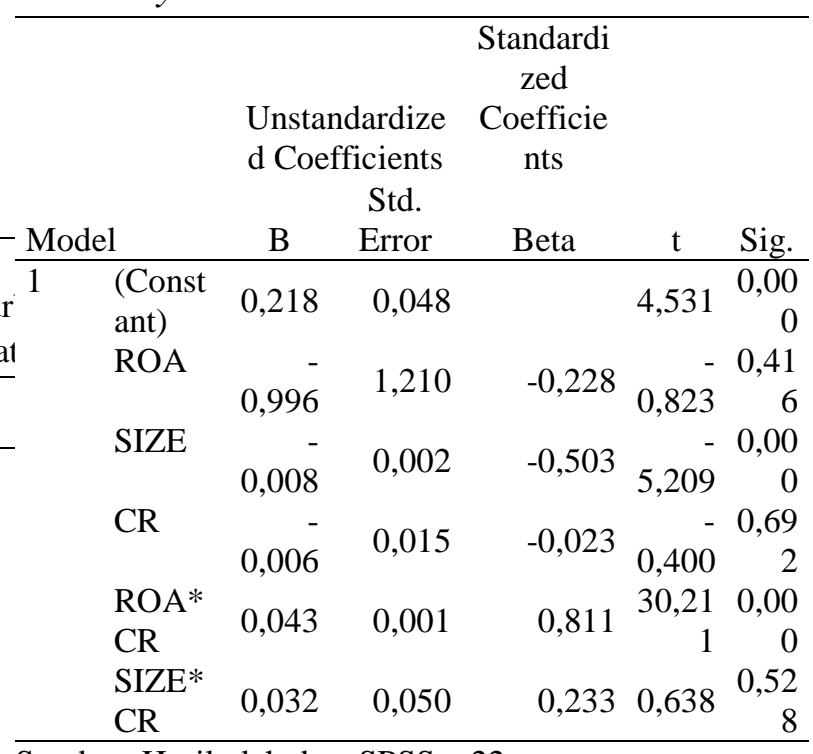

Sumber: Hasil olah data SPSS v.22

Berdasarkan hasil pengujian nilai sig. untuk variabel LNROA*LNCR sebesar 0,000 . Nilai tersebut lebih kecil dari alpha 0,05 atau $0,000<0,05$ dan koefisien regresi $\left(B_{3}\right)$ sebesar 0,043. Hal ini dapat disimpulkan bahwa current ratio memoderasi pengaruh return on assets terhadap dividend payout ratio.

Berdasarkan hasil pengujian menunjukkan nilai sig. untuk variabel SIZE*LNCR sebesar 0,528. Nilai tersebut lebih besar dari alpha 0,05 atau 0,528 > 0,05 dan koefisien regresi $\left(\beta_{4}\right)$ sebesar 0,032 . Hal ini dapat disimpulkan bahwa current ratio tidak memoderasi pengaruh firm size terhadap dividend payout ratio. 


\section{PEMBAHASAN}

1. Profitabilitas terhadap Dividend Payout Ratio

Hipotesis pertama ditolak, menyatakan bahwa profitabilitas tidak berpengaruh terhadap dividend payout ratio. Berdasarkan hasil analisis statistik diketahui bahwa thitung dari variabel Return on Assets sebesar

0,027 dengan nilai signifikansi 0,978. Nilai signifikansi tersebut lebih besar dari nilai alpha 0,05 atau 0,978>0,05. Maka dapat disimpulkan dalam pembagian jumlah dividen tidak selalu ditunjukkan dengan tinggi rendahnya laba atau profit yang diperoleh perusahaan. Besar kecil dividen yang diterima oleh para pemegang saham dapat didasarkan pada hasil keputusan Rapat Umum Pemegang Saham (RUPS). Keuntungan perusahaan tersebut dapat ditahan sebgai saldo laba atau dapat diinvestasikan kembali.

Hasil penelitian ini sesuai dengan hasil penelitian yang pernah dilakukan oleh Karauan (2017) yang menyataka bahwa Return on Assets (ROA) tidak berpengaruh terhadap Dividend Payout Ratio. Hal ini berarti apabila perusahaan mengalami kerugian sehingga tidak mampu membagikan dividen kepada pegang saham, maka dapat disimpulkan bahwa efektifitas manajemen dalam mengelola investasi kurang baik.

2. Firm Size terhadap Dividend Payou Ratio

Hipotesis kedua diterima, Firm size berpengaruh terhadap Dividend Payout Ratio. Berdasarkan hasil penelitian bahwa $t_{\text {hitung }}$ dari variabel Firm Size sebesar -3,189 dengan nilai signifikansi 0,003. Nilai signifikansi tersebut kecil besar dari nilai alpha 0,05 atau $0,003<0,05$. Hal ini menunjukkan bahwa perusahaan yang besar dan sudah mapan akan memiliki akses yang mudah untuk masuk dalam pasar modal, sementara perusahaan yang baru atau masih kecil akan mengalami kesulitan untuk memilik akses ke pasar modal. Karena kemudahan yang dimiliki perusahaan besar untuk memasuki pasar modal berarti kemampuan untuk memperoleh dana dari investor atau laba yang lebih besar, dengan demikian perusahaan akan mengurai saldo laba pada neraca untuk meningkatkan kemampuan perusahaan dalam membagikan dividen.

Hasil penelitian ini konsisten sejalan dengan penelitian yang pernah dilakukan oleh Yuwono dkk (2018) dan Atmoko dkk (2017) yang menyatakan bahwa Firm Size berpengaruh terhadap Dividend Payout Ratio. Semakin besarnya firm size, maka semakin besar pembagian dividen kepada pemegang saham.

3. Likuiditas Memoderasi Profitabilitas

Hipotesis ketiga $\begin{array}{r}\text { diterima, } \\ \text { likuiditas } \\ \text { menyatakan terhadap }\end{array}$
memoderasi profitabilitas ras
dividend payout ratio. Berdasarkan hasil
penelitian nilai signifikansi untuk
variabel LNROA*LNCR sebesar 0,000 .
Nilai tersebut lebih kecil dari alpha 0,05
atau 0,000<0,05 dan koefisien regresi
$\left(\beta_{3}\right)$ sebesar 0,043 . Hal ini berarti bahwa
likuiditas mampu meningkatkan
pembayaran dividen pada saat
profitabilitas tinggi dan likuiditas
mampu menurunkan pembayaran
dividen pada saat profitabilitas rendah.
Pada saat perusahaan ingin
menginvestasikan dana lebih banyak
akan dapat menyebabkan berkurangnya
dividen yang akan dibagikan kepada
pemegang saham, namun likuiditas
yang baik akan mampu menunda


pembayaran hutang jangka pendeknya, sehingga dana tersebut dapat digunakan untuk membagikan dividen.

Hasil penelitian ini sesuai dengan hasil penelitian yang pernah dilakukan oleh Parmitasari dkk (2015) bahwa likuiditas sebagai variabel moderating mampu memoderasi profitabilitas terhadap dividend payout ratio.

4. Likuiditas Memoderasi Firm Size

Hipotesis keempat menyatakan bahwa likuiditas tidak memoderasi firm size terhadap dividend payout ratio. Berdasarkan nilai signifikansi untuk variabel SIZE*LNCR sebesar 0,528. Nilai tersebut lebih besar dari alpha 0,05 atau 0,528>0,05 dan koefisien regresi $\left(ß_{4}\right)$ sebesar 0,032 . Hal ini terjadi karena perusahaan memiliki likuiditas yang baik akan cenderung tidak akan membagikan dividen kepada pemegang saham karena perusahaan lebih memilih untuk melunasi kewajibannya. Hal ini berarti bahwa likuiditas tidak mampu meningkatkan pembayaran dividen pada saat firm size tinggi dan likuiditas tidak mampu menurunkan pembayaran dividen pada saat firm size rendah.

\section{KESIMPULAN DAN SARAN \\ Kesimpulan}

1. Profitabilitas tidak berpengaruh terhadap Dividend payout ratio pada Perusahaan BUMN yang Terdaftar di Bursa Efek Indonesia Periode 20132017. Hal ini dibuktikan dengan hasil yang didapat dari tarif signifikansi sebesar 0,978 >0,05.

2. Firm Size berpengaruh terhadap Dividend Payout Ratio pada Perusahaan BUMN yang Terdaftar di Bursa Efek Indonesia Periode 2013-2017. Hal ini dibuktikan dengan hasil yang didapat dari tarif signifikansi sebesar 0,003 < 0,05 .

3. Likuiditas memoderasi pengaruh profitabilitas terhadap dividend payout ratio pada Perusahaan BUMN yang Terdaftar di Bursa Efek Indonesia Periode 2013-2017. Hal ini dibuktikan dengan hasil menunjukkan nilai signifikansi untuk variabel LNROA*LNCR sebesar 0,000. Nilai tersebut lebih kecil dari alpha 0,05 atau $0,000<0,05$.

4. Likuiditas tidak memoderasi pengaruh firm size terhadap dividend payout ratio pada Perusahaan BUMN yang Terdaftar di Bursa Efek Indonesia Periode 20132017. Hal ini dibuktikan dengan hasil menunjukkan nilai signifikansi untuk variabel SIZE*LNCR sebesar 0,528. Nilai tersebut lebih besar dari alpha 0,05 atau $0,528>0,05$.

\section{Saran}

1. Bagi Perusahaan

Bagi manajer perusahaan yang ingin meningkatkan kesejahteraan para pemegan saham dengan membagikan dividen, penelitian ini diharapkan dapat dijadikan informasi yang bisa digunakan dalam penambilan keputusan terhadap pembagian dividen, karena pada penelitian ini firm size berpengaruh terhadap dividend payout ratio.

2. Bagi Investor

Para investor disarankan untuk memperhatikan tingkat Firm Size perusahaan karena variabel tersebut berpengaruh terhadap Dividen Payout Ratio dalam pengambilan keputusan untuk menanakan modalnya.

3. Bagi Peneliti Selanjutnya

Dalam penelitian ini yang hanya diteliti terbatas pada beberapa variabel saja yaitu Profitabilitas (Return on 
Assets) dan Firm Size yang mempengaruhi Dividend Payout Ratio dengan variabel moderating Likuiditas (Current Ratio). Sedangkan faktorfaktor lain yang mempengaruhi Dividend Payout Ratio belum diungkapkan berapa besar pengaruhnya, peneliti selanjutnya diharapkan menambah faktor- faktor lain yang belum diteliti dalam penelitian ini.

\section{DAFTAR PUSTAKA}

Ano Rizky Rurniawan, Sri Murni, Paulina Van Rate. (2014). Pengaruh Likuiditas Dan Profitabilitas Terhadap Devidend Payout Ratio Pada Subsektor Perbankan Yang Terdaftar Di Bursa Efek Indonesia Periode 2009-2013. Jurnal EMBA. Vol.2 No.3 September, Hal. 884894.

Arjana I Putu Pande Hary, I. D. G. Dharma Suputra. (2017). Pengaruh Profitabilitas, Leverage, Ukuran Perusahaan dan Corporate Social Responsibility pada Kebijakan Dividen. E-Jurnal Akuntansi Universitas Udayana, Vol.21.3. Desember: 2021-2051

Atmoko Yudha, F. Defung, dan Irsan Tricahyadinata. (2017). Pengaruh return on assets, debt to equity ratio, dan firm size terhadap dividend payout ratio. Fakultas Ekonomi dan Bisnis Universitas Mulawarman, Samarinda. Vol.14 (2) Hal. 103-109

Fahmi Irham. (2014). Manajemen Keuangan Perusahaa dan Pasar Modal. Jakarta: Mitra Wacana Media.

Ghozali Imam. (2016). Aplikasi Analisis Multivariete dengan Program IBM SPSS 23. Edisi 8. Semarang: Badan Penerbit Univ. Diponegoro.

Harun Sulfikram. (2018). Pengaruh Profitabilitas. Free Cash Flow, Leverage, Likuiditas dan Size Terhadap Dividend Payout Ratio Perusahaan Manufaktur yang Terdaftar di Bursa Efek Indonesia. Jurnal Riset Akuntansi, Univ.
Khairun Ternate, Vol. 5 No. 2 Hal. 122-137

Karuan Prisilia, Sri Murni, Joy Tulung. (2017). Pengaruh Kinerja Keuangan Terhadap Kebijakan Dividen Pada Bank Bumn Yang Go Public Di Bursa Efek Indonesia Tahun 20112015. Jurnal EMBA. Universitas Mulawarman, Samarinda. Vol.5 No.2 Juni, Hal. 935-944

Kasmir S.E., M.M. (2010). Pengantar Manajemen Keuangan. Edisi 2. Jakarta: Prenadamedia Group.

Parmitasari Rika Dwi Ayu, Sutrisna. (2015). Pengaruh Profitabilitas Terhadap Kebijakan Dividen Tunai Dengan Likuiditas Sebagai Variabel Moderasi (Studi Terhadap Perusahaan Consumer Goods yang Terdaftar di Bursa Efek Indonesia Periode 2010- 2014. Fakultas Ekonomi dan Bisnis Islam Universitas Islam Negeri Alauddin Makasar.

Sabri Fitri Handayani, Dwi Risma Deviyanti, dan Indra Suyoto Kurniawan. 2017. Pengaruh Kinerja Keuangan Terhadap Dividend Payout Ratio studi empiris pada Perusahaan BUMN.Fakultas Ekonomi dan Bisnis Universitas Mulawarman, Samarinda. Vol. 14 (1) Hal. 24-30

Samryn, L. M. (2015). Pengantar Akuntansi. Jakarta: PT. Raja Grafindo Persada.

Sanjaya I Made Marta, I Wayan Pradnyantha Wirasedana. (2018). Faktor - Faktor yang Memengaruhi Dividend Payout Ratio Perusahaan Manufaktur Sektor Industri Barang Konsumsi. E-Jurnal Akuntansi, Univ.Udayana, Vol.24 No.2 Hal. 988-1016

Sugiyono. (2016). Metode Penelitian Kuantitatif Kualitatif dan $R \& D$. Bandung : Alfabeta

Yunisari Ni Wayan, Ni Made Dwi Ratnadi. (2018). Pengaruh Profitabilitas dan Kepemilikan Manajerial pada Kebijakan Dividen dengan Likuiditas sebagai Variabel 
Moderasi. E-Jurnal Akuntansi, Univ.Udayana, Vol. 23, No. 1 Hal. 379-405

Yuwono Wahyu dan Indah Kurniawati. (2018). Faktor- faktor yang
Mempengaruhi Dividend Payout Ratio Pada Perusahaan Manufaktur Indonesia. Jurnal Reksa, Univ. Ahmad Dahlan Vol. 5 No. 1 Hal. $11-21$ 